KS. JAN MACIEJ DYDUCH

Wydział Prawa Kanonicznego

Uniwersytetu Papieskiego Jana Pawła II w Krakowie

\title{
POGRZEB KOŚCIELNY WYRAZEM WIARY CHRZEŚCIJAŃSKIEJ. AKTUALNY STAN PRAWNY
}

Treść: Wstęp. - 1. Cele pogrzebu. - 2. Komu należy przyznać pogrzeb kościelny, a komu odmówić? - 3. Dopuszczalność kremacji zwłok. - Zakończenie.

\section{Wstęp}

W centrum wiary chrześcijańskiej jawi się prawda o zmartwychwstaniu Jezusa Chrystusa. Ona jest źródłem prawdy o powszechnym zmartwychwstaniu ciał w Dzień Ostateczny. Pogrzeb katolicki zwany w Kodeksie Prawa Kanonicznego (=KPK) „pogrzebem kościelnym” wyraża wiarę w dogmat o zmartwychwstaniu, który głosi Kościół od zarania swoich dziejów. To Kościół ustanawia normy grzebania swoich wiernych, w których zaznacza: komu przyznać pogrzeb katolicki, a także określa dopuszczenie kremacji zwłok, te zagadnienia będą przedmiotem naszych rozważań. Ustanawiając dyscyplinę grzebania wiernych zmarłych, Kościół współpracuje z prawodawstwem świeckim, dotyczącym w szczególności miejsca pochówku.

\section{Cele pogrzebu}

Sobór Watykańskim II naucza: „Syn Boży, zwyciężając śmierć w zjednoczonej z Nim ludzkiej naturze, przez swoją śmierć i zmartwychwstanie odkupił człowieka i przemienił go w nowe stworzenie"1.

\footnotetext{
${ }^{1}$ Konstytucja soborowa Lumen gentium (= KK), n. 7.
} 
Jezus Chrystus głosząc Ewangelię, wielokrotnie zaznaczał i podkreślał prawdę o swoim zmartwychwstaniu, dodając iż zmartwychwstaną także wszyscy umarli (por. Mk 12, 18-27). Prawdę o zmartwychwstaniu Chrystusa podejmuje Kościół pierwotny. Naucza św. Paweł Apostoł: „przekazałem wam na początku to, co przejąłem; że Chrystus umarł- zgodnie z Pismem- za nasze grzechy, że został pogrzebany, że zmartwychwstał trzeciego dnia zgodnie z Pismem; że ukazał się Kefasowi, a potem Dwunastu, później zjawił się więcej niż pięciuset braciom równocześnie..." (1 Kor 15, 3-6).

Prawda o zmartwychwstaniu Chrystusa jest wiodąca w nauczaniu pierwotnego Kościoła. To nauczanie akcentuje, że zmartwychwstały Jezus jest źródłem i początkiem przyszłego zmartwychwstania wiernych. Naucza św. Paweł Apostoł, że Chrystus zmartwychwstał jako pierwszy spośród tych co pomarli, a ponieważ przez człowieka przyszła śmierć, przez Człowieka dokona się zmartwychwstanie: „I jak w Adamie wszyscy umierają, tak też w Chrystusie wszyscy będą ożywieni, lecz każdy według własnej kolejności” (1 Kor 15, 22-23).

Chrześcijanin uczestniczy w zmartwychwstaniu Chrystusa, gdyż przez chrzest zostaje zanurzony w Jego śmierć i zmartwychwstanie. Św. Paweł naucza: „Zatem przez chrzest zanurzający nas w śmierć zostaliśmy razem z Nim pogrzebani po to, abyśmy i my wkroczyli w nowe życie- jak Chrystus powstał z martwych dzięki chwale Ojca. Jeżeli bowiem przez śmierć, podobną do Jego śmierci, zostaliśmy z Nim złączeni w jedno, tak samo będziemy z Nim złączeniu w jedno przez podobne zmartwychwstanie" (Rz 6, 4-5). Chrześcijanin od czasu chrztu nosi w sobie zadatek zmartwychwstania. Dlatego pogrzeb chrześcijanina głosi prawdę o jego przejściu do życia wiecznego i wyczekiwanie na zmartwychwstanie. Wyznajemy to, odmawiając „Skład Apostolski”: „Wierzę w ciała zmartwychwstanie i żywot wieczny".

Przez chrzest człowiek jednoczy się z Chrystusem zmartwychwstałym i uczestniczy w Jego życiu, gdyż On po wniebowstąpieniu przebywa w wiecznej chwale w niebie. Dlatego Kościół głosi: „Albowiem życie Twoich wiernych, o Panie, zmienia się, ale się nie kończy, i gdy rozpadnie się dom doczesnej pielgrzymki znajdą przygotowane 
w niebie wieczne mieszkanie" ${ }^{2}$. W momencie śmierci dusza ludzka opuszcza ciało, lecz w zmartwychwstaniu Bóg przywróci niezniszczalne życie uwielbionemu i przekształconemu ciału ludzkiemu, jednocząc je ponownie z duszą. Sobór Watykański II polecił, aby odnowiony obrzęd pogrzebu lepiej wyrażał prawdę o tym, że śmierć jest przejściem do życia wiecznego i zadatkiem zmartwychwstania: „Obrzęd pogrzebu powinien jaśniej wyrażać paschalny charakter śmierci chrześcijan oraz lepiej odpowiadać warunkom i tradycjom poszczególnych regionów..."3.

Mając na uwadze powyższą naukę Pisma Świętego o śmierci, życiu wiecznym i zmartwychwstaniu oraz wskazania Vaticanum II, Kościół prezentuje to w odnowionych obrzędach pogrzebu. Tak więc mają one głosić i pogłębiać wiarę w prawdy ostateczne: „W obrzędach pogrzebowych swoich dzieci Kościół obchodzi z wiarą paschalne misterium Chrystusa i modli się, aby Ci, którzy przez chrzest zostali wszczepieni w chrzest i zmartwychwstanie Chrystusa, z Nim przeszli przez śmierć do życia”" . Kościół niesie pomoc duchową zmarłym, składając za nich Ofiarę Eucharystyczną, modląc się za nich i spełniając inne praktyki pobożne np. zyskiwanie odpustów ofiarowanych za zmarłych ${ }^{5}$.

Chrześcijanie, odprawiając i uczestnicząc w obrzędach pogrzebowych, winni starać się wyrażać nadzieję życia wiecznego. Mają także uwzględniać tradycje rodzime, zwyczaje lokalne i praktyki stowarzyszeń pogrzebowych, które są zgodne z prawdami wiary chrześcijańskiej. To zaś, co jest im przeciwne, należy albo wyeliminować, albo tak przekształcić, aby pogrzeby chrześcijańskie wyrażały wiarę w zmartwychwstanie i prawdziwego ducha ewangelicznego ${ }^{6}$. W obrzędach pogrzebowych winno okazać się szacunek ciałom zmarłych wiernych, które były świątyniami Ducha Świętego. W czasie między

\footnotetext{
${ }^{2}$ Prefacja ze mszy za zmarłych, Mszał Rzymski.

${ }^{3}$ Konstytucja soborowa Sacrosanctum Concilium (=KL), n. 81.

${ }^{4}$ Wprowadzenie teologiczne i pastoralne, w: Obrzędy pogrzebowe dostosowane do zwyczajów diecezji polskich, Katowice 1977, n. 1.

${ }^{5}$ Por. tamże, n. 1-14.

${ }^{6}$ Por. tamże, n. 2.
} 
śmiercią a pochowaniem zmarłego, wyznając wiarę w życie wieczne i modląc się za zmarłego wyrazić szacunek dla jego ciała, np. przez czuwanie przy zwłokach zmarłego, przez gromadzenie się rodziny i sąsiadów przy trumnie na liturgii Słowa ${ }^{7}$.

W obrzędach pogrzebowych nie wolno zapominać o bliskich, krewnych, przyjaciołach i znajomych osoby zmarłej „...ż̇ywym należy nieść pociechę nadziei" (kan. 1176, par. 2 KPK). Obrzędy pogrzebowe mają wyrażać troskę o zbawienie wieczne nie tylko osoby zmarłej, lecz także o zbawienie uczestników pogrzebu. Chodzi tu szczególnie o następującą sytuację: obecnie, gdy coraz bardziej szerzy się dechrystianizacja, zeświecczenie i zaniedbywanie praktyk religijnych, obrzędy pogrzebowe mogą stać się dogodną sposobnością duszpasterską, do ewangelizacji tych, którzy zaprzestali życia z wiary ${ }^{8}$.

Za należyte odprawianie obrzędów pogrzebowych odpowiedzialna jest cała wspólnota wiernych, jednak szczególna odpowiedzialność spoczywa na szafarzu obrzędów. Jego zadaniem jest tak przewodniczyć obrzędom, aby zostały wypełnione cele pogrzebu: „Niech także pamiętają wszyscy, a zwłaszcza kapłani, gdy w obrzędach pogrzebowych polecają zmarłych Bogu, że ich obowiązkiem jest umacniać nadzieję uczestników pogrzebu i ożywić wiarę w tajemnicę paschalną oraz zmartwychwstanie umarłych i to w taki sposób, aby okazując macierzyńską miłość Kościoła i niosąc pociechę płynącą z wiary, podnieść na duchu wierzących, a nie urazić pogrążonych w żałobie" Tak więc celem pogrzebu chrześcijańskiego jest nie tylko zmarły, lecz także wspólnota, w której żył.

Przywołane postanowienie rytuału pogrzebowego bez wątpienia wskazuje na to, że szafarzem obrzędów pogrzebowych winien być przede wszystkim kapłan. Centralnym bowiem ich elementem, jest Ofiara Eucharystyczna, która jest najskuteczniejszym sposobem niesienia pomocy zmarłym, a ją sprawować może prezbiter albo

\footnotetext{
${ }^{7}$ Por. tamże, n. 3; por. kan. 1176 par. 2 KPK.

${ }^{8}$ Instrukcja międzydykasterialna Eccelsiae de mysterio, 15.08.1997, L'Osservatore Romano 19 (1998), n. 12, s. 39, art. 12, wyd. pol.

${ }^{9}$ Obrzędy pogrzebu..., n. 17.
} 
biskup (por. kan. 900 KPK). Pozostałe obrzędy pogrzebowe mogą być odprawiane przez diakona. Wierni świeccy mogą przewodniczyć obrzędom żałobnym, tylko w przypadku braku wyświęconego szafarza, i z zachowaniem przepisów liturgicznych ${ }^{10}$. Przepisy polskie zezwalają, aby - w przypadku braku kapłana lub diakona obrzędom w domu oraz w drodze do kościoła mógł przewodniczyć świecki katolik upoważniony przez proboszcza ${ }^{11}$.

Wyrazem szacunku dla zmarłego, w szczególności dla jego ciała, jest właściwe miejsce pochówku. $Z$ reguły miejscem tym jest cmentarz. Sprawę tę regulują zarówno przepisy kościelne, jak i przepisy państwowe. W Polsce miejscu przeznaczonemu do grzebania zmarłych przysługuje ochrona państwa, która zapewnia mu nienaruszalność. Gwarantuje ją Konkordat Polski z 1993 roku $^{12}$. Tematem tym, zajmuje się także ustawa państwowa, zapewniająca wyznawcom innych religii i niewierzącym prawo do grzebania na cmentarzach wyznaniowych bez jakiejkolwiek dyskryminacji ${ }^{13}$. Konkordat Polski zapewnia także Kościołowi katolickiemu swobodę wykonywania kultu publicznego, w tym wszystkich ceremonii liturgicznych związanych z pogrzebem kościelnym ${ }^{14}$. W tej dziedzinie ustawodawstwo państwowe nie może wprowadzać żadnych ograniczeń czy zmian. Natomiast polskie prawodawstwo państwowe reguluje wiele innych spraw związanych z pochówkiem zmarłych, np. pogrzeb dzieci martwo urodzonych, czy przygotowanie do pochówku zwłok pacjentów zmarłych w podmiotach leczniczych. Normy te i im podobne zostały szczegółowo omówione podczas sympozjum urządzonym dnia 30.03.2017 roku przez Wydział Prawa Kanonicznego Uniwersytetu Papieskiego Jana Pawła II w Krakowie. Sympozjum to miało wiodący temat: „,Pogrzeb

\footnotetext{
${ }^{10}$ Instrukcja Ecclesiae de mysterio, art. 12.

${ }^{11}$ Por. Obrzędy pogrzebu... n. 22, s. 20.

${ }^{12}$ Konkordat między Stolica Apostolskq i Rzeczpospolita Polskq 1993, Dz. U. 23.04.1998, nr. 51, poz. 318 , art. 8 u. 3 i 5.

${ }^{13}$ Por. Ustawa o zmianie ustawy o cmentarzach i chowaniu zmarlych, 26.06.1997, Dz. u. 15.10.1997, nr 126, poz. 805.

${ }^{14}$ Por. Konkordat Polski 1993, art. 5 i 8 u. 1-2.
} 
w prawie kanonicznym i prawie świeckim”, którego materiały zostaną opublikowane.

Szanując wolność wyznania i kultu zabezpieczone w Konkordacie 1993, państwo nie ingeruje w to, komu należy przyznać, a komu odmówić pogrzebu kościelnego.

\section{Komu należy przyznać pogrzeb kościelny, a komu odmówić?}

Powiedzieliśmy wyżej, iż w obrzędach pogrzebu kościelnego winny jawić się prawdy ostateczne o śmierci i życiu wiecznym w kontekście śmierci i zmartwychwstania Jezusa. To On pozwolił, że po Jego śmieci uczniowie urządzili mu pogrzeb. Został pochowany w grobie, „...w którym trzy dni spoczywał”. Naśladując Jezusowy pogrzeb, chrześcijanie od początku istnienia Kościoła, urządzali pogrzeby wiernym zmarłym, głosząc prawdę o ich zmartwychwstaniu w Dniu Ostatecznym. KPK reguluje nie tylko przebieg uroczystości pogrzebowych (por. kan. 1177-1182 oraz 1240-1242), które należałoby odrębnie omówić, lecz także odpowiada na pytanie: komu należy przyznać pogrzeb kościelny, a komu odmówić.

Podstawowa norma ma charakter ogólny: „Wierni zmarli powinni otrzymać pogrzeb kościelny, zgodnie z przepisami prawa” (kan. 1176 par. $1 \mathrm{KPK})$. Z wiernymi odnośnie do urządzania pogrzebu, zrównani są katechumeni (por. kan. 1183 par. 1 KPK). Pogrzeb kościelny można urządzić dla dzieci, których rodzice mieli zamiar je ochrzcić, a które zmarły przed chrztem. W tych przypadkach trzeba uzyskać zezwolenie ordynariusza miejsca (por. kan. 1183, par. 2 KPK). Konferencja Episkopatu Polski udzieliła ogólnego zezwolenia na takie pogrzeby ${ }^{15}$. Osobom ochrzczonym należącym do jakiegoś Kościoła lub wspólnoty niekatolickiej można urządzić pogrzeb kościelny pod następującymi warunkami: a) zezwolenie ordynariusza miejsca, b) brak ich własnego szafarza, c) za życia nie byli wyraźnie przeciwni takiemu pogrzebowi (por. kan. 1183 par. $3 \mathrm{KPK}$ ). W przywołanych okolicznościach duszpasterz winien zachować należną delikatność i ostrożność kierując się zasadami ekumenizmu.

${ }^{15}$ Por. Obrzędy pogrzebu... n. 22, s. 20. 
Pogrzebu kościelnego mają być pozbawieni jawni grzesznicy, którzy przed śmiercią nie dali żadnych oznak pokuty i którym przyznanie pogrzebu spowodowałoby zgorszenie wiernych (por. kan. 1184 par. 1 n. $3 \mathrm{KPK})$. Jeśli jednak grzesznicy ci dali oznaki pokuty, to nie należy ich pozbawiać pogrzebu kościelnego. Taką decyzję podjęła Kongregacja Doktryny Wiary, stwierdzając, że nie należy odmawiać pogrzebu publicznym grzesznikom, jeżeli przed śmiercią dali jakieś oznaki pokuty i wyklucza się publiczne zgorszenie wiernych ${ }^{16}$. Do takich znaków pokuty, których zaistnienie mają potwierdzić wiarygodni świadkowie należą: prośba o kapłana (choćby nie zdążył przybyć), publiczne wzbudzenie żalu za grzechy, ucałowanie krzyża, przeproszenie za dane zgorszenie, itp. Publiczne zgorszenie wyklucza się przez to, że wiernych informuje się o tych znakach pokuty ${ }^{17}$. Podobnie traktuje się wiernych, którzy żyli w niesakramentalnym małżeństwie, jeżeli przed śmiercią dali znaki pokuty i wykluczone zostało publicznego zgorszenie wiernych ${ }^{18}$. W zastosowaniu formy pogrzebu trzeba uwzględnić różne sytuacje osób żyjących bez sakramentalnego małżeństwa, np. czy mogli je zawrzeć, jak spełniali dostępne im praktyki religijne, czy dbali o katolickie wychowanie potomstwa. Wydaje się, że na urządzanie pogrzebu kościelnego dla zmarłych żyjących w małżeństwach niesakramentalnych trzeba spojrzeć w optyce posynodalnej adhortacji papieża Franciszka „Amoris leatitia”. Naucza ona: „Ważne, aby osoby rozwiedzione żyjące w nowych związkach odczuwały, że są częścią Kościoła, że nie są ekskomunikowani, i nie są traktowane jako takie, bo zawsze tworzą wspólnotę kościelną"19.

Pogrzebu katolickiego nie należy urządzać notorycznym apostatom, heretykom i schizmatykom, jeśli przed śmiercią nie dali żadnych

\footnotetext{
${ }^{16}$ Por. Dekret Patres Sacrae Congregationis, 20.09.1973, AAS 65 (1973), s. 500.

${ }^{17}$ Por. Konferencja Episkopatu Polski, Instrukcja liturgiczno-duszpasterska o pogrzebie i modlitwach za zmarlych, 5.05.1978, n. 14, w: Dokumenty duszpastersko-liturgiczne Episkopatu Polski 1966-1998, opr. Cz. Krakowiak, L. Adamowicz, Lublin 1999, s. 279-284.

${ }^{18}$ Por. tamże n. 15.

${ }^{19}$ Franciszek, Adhortacja Amoris Laetitia, 19.03.2016, kopia wg wyd. watykańskiego, Kraków 2016, n. 243.
} 
oznak pokuty (por. kan. 1184 par. 1 n. 1 KPK). Traktuje się wymienionych inaczej niż braci odłączonych, o których mówiliśmy wyżej, a którym w określonych okolicznościach można urządzić pogrzeb. Zazwyczaj jako braci odłączonych traktujemy tych, którzy urodzili się i wychowali w innej religii chrześcijańskiej i są przekonani o jej prawdziwości. Pozbawić pogrzebu kościelnego należy tych katolików, którzy za życia wybrali spalenie swojego ciała z motywów przeciwnych wierze chrześcijańskiej, np. aby zaprzeczyć prawdzie o zmartwychwstaniu ciał (por. kan. 1184 par. 1 n. 2 KPK). Sprawę tę szerzej omówimy w następnym punkcie o kremacji zwłok.

KPK zajmuje odmienne stanowisko od KPK z 1917 r. w sprawie pogrzebów samobójców. KPK z 1917 roku stwierdza, że należy pozbawić pogrzebu kościelnego samobójców, którzy z rozmysłem odebrali sobie życie (por. kan. 1240 par. 1 n. 3). Fakt samobójstwa i jego poczytalność musiały być pewne. W zakresie zewnętrznym przypuszczało się że samobójstwo zostało popełnione z rozmysłem, dopóki nie udowodniło się czegoś innego ${ }^{20}$. KPK 1983 nie wymienia samobójców wśród tych, których należy pozbawić pogrzebu. Takie stanowisko wynikło z powszechnej opinii psychiatrów głoszącej, iż samobójcy nie są w pełni odpowiedzialni za swój czyn. Dlatego nie odmawia się im pogrzebu, jeżeli w ciągu życia okazywali przywiązanie do wiary i Kościoła ${ }^{21}$. Stąd, urządzenie pogrzebu samobójcy zależeć będzie od jego dotychczasowego życia. W przypadku, gdyby udowodniono samobójstwo z rozmysłem, co wydaje się bardzo trudne, należy takiemu samobójcy odmówić pogrzebu kościelnego, traktując go jako jawnego grzesznika.

Niekiedy przy załatwianiu pogrzebu mogą zaistnieć duże trudności, wówczas prawodawca przychodzi z pomocą duszpasterzom, dając możliwość zwrócenia się do ordynariusza miejsca (por. kan. 1182, par. $2 \mathrm{KPK})$. Do ordynariusza miejsca duszpasterz winien zwrócić się pisemnie, przedstawiając dokładnie sprawę, a w razie potrzeby załączając zeznania wiarygodnych świadków. Duszpasterz powinien

\footnotetext{
${ }^{20}$ Por. F. BĄczkowicz, Prawo kanoniczne, t. 2, wyd. 3, Opole 1958, s. 410-411.

${ }^{21}$ Por. Instrukcja liturgiczno-duszpasterska... n. 13.
} 
pamiętać, że czas między śmiercią a pogrzebem jest krótki, że w tym czasie rodzina zmarłego musi załatwić wiele spraw związanych z pogrzebem, to też nie należy jej stwarzać dodatkowych, niepotrzebnych trudności.

Jeśli komuś odmówiono urządzenia pogrzebu kościelnego, to nie przysługuje mu także msza św. pogrzebowa (por. kan. $1185 \mathrm{KPK}$ ). Chodzi tu tylko o uroczystą mszę pogrzebową, co nie wyklucza możliwości odprawienia mszy św. za zmarłego pozbawionego pogrzebu kościelnego. Także odmówienie pogrzebu nie jest wyrokiem potępiającym takiego zmarłego.

\section{Dopuszczalność kremacji zwłok}

Aktualnie Kościół dopuszcza kremację zwłok wiernych zmarłych: „Kościół usilnie zaleca zachowanie pobożnego zwyczaju grzebania ciał zmarłych. Nie zabrania jednak kremacji, jeśli nie została wybrana z pobudek przeciwnych nauce chrześcijańskiej" (kan. 1176 par. 3 KPK). Przywołana zasada różni się od normy kodeksowej z 1917 r. Wówczas to kremacja była surowo zakazana, a wierni, którzy za życia wyrazili wolę jej dokonania, byli pozbawiani pogrzebu kościelnego (por. kan. 1203 i 1240 par. 1 n. 5 KPK 1917). Ta dyscyplina była podyktowana motywacją dokonywania kremacji. Jej propagowanie w przeszłości łączyło się często z antykościelnymi ideami naturalistycznymi i wolnomularskimi kwestionującymi naukę Kościoła o nieśmiertelności duszy ludzkiej i o zmartwychwstaniu ciał. Na skutek tego obowiązywała presumpcja prawna stwierdzająca, że każdy domagający się kremacji kieruje się motywami wrogimi Kościołowi ${ }^{22}$. Z biegiem lat, gdy kremacja była praktykowana, np. w czasie wojen czy panowania zarazy, jak również ze względów praktycznych, np. przy masowej migracji w czasie wojen światowych i po ich zakończeniu, która powodowała częste transporty zwłok, przywołana presumpcja traciła swoje znaczenie i zaczęła wygasać. Przestała obowiązywać od opublikowania instrukcji „Piam et constantem”. Dopuszczała ona kremację

\footnotetext{
${ }^{22}$ Por. P. Majer, Pogrzeb kościelny, w: Komentarz do Kodeksu Prawa Kanonicznego, red. J. Krukowski, t. 3, 2, Poznań 2011, s. 388.
} 
zmarłych, jeśli nie została dokonana z motywów sprzecznych z nauką Kościoła, przy czym preferowała tradycyjne grzebanie zwłok ${ }^{23}$.

W świetle powyższych stwierdzeń nie należy uważać kremacji za coś złego, bowiem sama w sobie nie jest zła. Nie wymaga się słusznej przyczyny, aby ją wybrać. Jedynie zła, a tym samym zabroniona, może stać się z powodu motywu jej wyboru, którym jest negacja prawd wiary. Zrozumiała jest również preferencja grzebania ciał zmarłych, gdyż ono lepiej wyraża wiarę w zmartwychwstanie i lepiej oddaje cześć ciału zmarłego ${ }^{24}$. W oparciu o wskazania przywołanej instrukcji „Piam et constantem” bezprzedmiotowa stała się presumpcja prawna zakładająca niegodziwość kremacji.

Wskazania omawianej instrukcji kształtowały praktykę dotyczącą kremacji w okresie posoborowym i weszły do KPK z 1983 r. Jak wspominaliśmy wyżej, dopuszcza on praktykowanie kremacji, preferuje tradycyjne grzebanie ciał i traktuje osoby, które wybrały kremację z motywów przeciwnych wierze jako jawnych grzeszników, których należy pozbawić pogrzebu kościelnego (por. kan. 1176 par. 2 i 1184 par. 1 n. 2 KPK). Podobne unormowanie sprawy kremacji zawiera Kodeks Kanonów Kościołów Wschodnich (KKKW) kan. 875-877.

Rozszerzanie się praktyki kremacji zwłok i związane z tym nadużycia sprawiły potrzebę nowych uregulowań prawnych na ten temat. Dokonała tego instrukcja: „Ad resurgendum cum Christo” ${ }^{25}$. Powtarza ona dotychczasową zasadę teologiczną: „Kościół nie dostrzega przyczyn doktrynalnych, by zakazać takiej praktyki, jako że kremacja zwłok nie dotyka duszy i nie uniemożliwia boskiej wszechmocy wskrzeszenia ciała, a więc nie zawiera obiektywnego zaprzeczenia doktryny chrześcijańskiej na temat nieśmiertelności duszy i zmartwychwstania ciała"26. Po przypomnieniu nauki Kościoła instrukcja

\footnotetext{
${ }^{23}$ Por. Kongregacja Świętego Oficjum, Instrukcja Piam et constantem, 8.05.1963, AAS 56 (1964), s. 822-823.

${ }^{24}$ Por. J. T. Martin De Agar, Pogrzeb kościelny, w: Kodeks prawa kanonicznegokomentarz, red. P. Majer, Kraków 2011, s. 882.

${ }^{25}$ Kongregacja Doktryny Wiary, Instrukcja Ad resurgendum cum Christo, 15.08.2016, maszynopis.

${ }^{26}$ Tamże, n. 4.
} 
przechodzi do wskazań praktycznych. Nakazuje ona, aby prochy zmarłego były przechowywane w miejscu świętym, to znaczy na cmentarzu lub kościele. Przyczynia się to do przypominania krewnym, znajomym i wspólnocie chrześcijańskiej o pamięci modlitewnej za zmarłych. $Z$ tych powodów przechowywanie prochów w miejscu zamieszkania jest zabronione. Wyjątkowo w przypadku ważnych okoliczności, zależnych od uwarunkowań kulturowych o charakterze lokalnym, ordynariusz może udzielić zezwolenia na przechowywanie prochów w miejscu zamieszkania, w porozumieniu z Konferencją Biskupią lub Synodem Biskupów Kościołów Wschodnich, przy zachowaniu odpowiednich warunków przechowywania i należnego prochom szacunku ${ }^{27}$.

Instrukcja zabrania rozrzucania prochów w powietrzu, na ziemi, lub w wodzie, albo w inny sposób. Zakazuje również przerabiania kremowanych prochów na pamiątki, biżuterię czy inne przedmioty. Takie praktyki są częstym przejawem popierania idei panteistycznych, naturalistycznych lub nihilistycznych sprzecznych z doktryną katolicką. Jeśliby zmarły za życia notorycznie żądał kremacji połączonej $z$ rozrzuceniem własnych prochów, to należy odmówić mu urządzenia pogrzebu kościelnego ${ }^{28}$.

Nawiązując do wskazań Kościoła powszechnego, biskupi polscy podali wytyczne dotyczące urządzania pogrzebów skremowanych zwłok ludzkich ${ }^{29}$. List Episkopatu Polski uzasadnia pierwszeństwo grzebania ciał zmarłych przed kremacją. Przestrzega przed zakazanymi praktykami łączonymi z kremacją, np. rozsypywaniem prochów w tak zwanych ogrodach pamięci, czy przechowywaniem ich w domu. Nakazuje, aby obrzędy pogrzebowe ze mszą św. i ostatnim pożegnaniem włącznie były celebrowane przed kremacją ${ }^{30}$. Podobne

\footnotetext{
${ }^{27}$ Por. tamże, n. 5-6.

${ }^{28}$ Por. tamże, n. 7-8.

${ }^{29}$ Por. Konferencja Episkopatu Polski, List o szacunku dla ciała zmarłego i obrzędach pogrzebu w przypadku kremacji, 16.10.2011, Akta Konferencji Episkopatu Polski 20 (2011) nr 2, s. 51-53; Dodatek do obrzędów pogrzebu związane z kremacja zwłok, Wprowadzenie, Katowice 2010.

${ }^{30}$ List Episkopatu..., n. 3-4.
} 
postanowienie, w szczególności o odprawieniu mszy św. pogrzebowej i innych ceremonii zawiera uzupełnienie do rytuału pogrzebowego ${ }^{31}$.

Obydwa przywołane dokumenty dopuszczają wyjątki. W uzasadnionych przypadkach, np. po sprowadzeniu urny z prochami z zagranicy, obrzędy pogrzebowe łącznie ze mszą św. można sprawować nad samą urną, którą stawia się przed prezbiterium, obok zapalonego paschału, podobnie kiedy uczestnicy pogrzebu przybywają z daleka i trudno im być na dwóch częściach pogrzebu, czyli na mszy św. połączonej z ostatnim pożegnaniem i po pewnym czasie na obrzędzie złożenia urny w grobie czy kolumbarium ${ }^{32}$. Wyjątki sprawowania zwyczajnych obrzędów pogrzebowych przy urnie z prochami są dość liczne. Jest to spowodowane tym, że normy kościelne dotarły do świadomości wiernych dopiero wówczas, gdy inna praktyka była już dość szeroko stosowana. Dlatego przestrzeganie właściwych - w tej dziedzinie - norm kościelnych winno być przedmiotem katechezy i wychowywania wiernych.

\section{Zakończenie}

Prawda o zmartwychwstaniu jawi się jako źródło inspirujące dla norm regulujących obrzędy pogrzebowe wiernych zmarłych. Kościół ma prawo je określać jak również rozstrzygać komu przyznać pogrzeb kościelny a komu odmówić. Rygorystyczne normy, dotyczące tej sprawy zostały w ostatnich dziesiątkach lat bardzo złagodzone. KPK z 1983 r. i inne dokumenty kościelne są wyrazem zmieniającej się w tej dziedzinie dyscypliny kanonicznej. Na szczególną uwagę zasługuje dopuszczenie kremacji zwłok, która przestała być zakazana. Niektóre sprawy związane z pogrzebem, winny być uregulowane we współpracy prawodawstwa kanonicznego z prawodawstwem państwowym.

\footnotetext{
${ }^{31}$ Por. Dodatek..., Wprowadzenie, n. 5.

${ }^{32}$ List Episkopatu Polski..., n. 4; Dodatek..., Wprowadzenie 5 c.
} 


\section{Church funeral as the expression of Christian faith - actually binding norms}

A ceremony of church funeral should be performed in the way that would express the truth about the Risen Christ and about the redemption of our bodies and eternal life. Canonical norms regulating the matter to whom the church funeral should be granted or not have been changed in the recent dozens of years. The change was from the rigorous model to more moderate especially in the case of the suicides or the Faithfull who had chosen the cremation of their bodies. The church legislation prefers traditional burial but permits cremation provided that the choice does not demonstrate a denial of faith in the resurrection of the body.

SŁOWA KLUCZOWE: pogrzeb kościelny; prawdy ostateczne; oznaki pokuty; kremacja

KEY WORDS: church funeral; ultimate truths; signs of repentance; cremation

\section{Nota o Autorze:}

Ks. PROF. DR HAB. JAN DYDUCH - w latach 2004-2009 rektor Papieskiej Akademii Teologicznej w Krakowie, a od 2009 do 2010 Uniwersytetu Papieskiego Jana Pawła II, profesor zwyczajny kierownik Katedry Prawa Osobowego i Ustroju Kościoła na Wydziale Prawa Kanonicznego UPJPII. 